\title{
Elmada mavi küfe neden olan Penicillium expansum'a karşı borik asitin antifungal etkisi
}

\section{Antifungal effect of boric acid against Penicillium expansum, the casual agent of blue mold of apple}

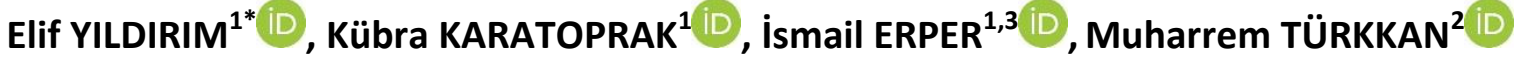 \\ ${ }^{1}$ Ondokuz Mayıs Üniversitesi, Ziraat Fakültesi, Bitki Koruma Bölümü, Samsun, Türkiye \\ ${ }^{2}$ Ordu Üniversitesi, Ziraat Fakültesi, Bitki Koruma Bölümü, Ordu, Türkiye \\ ${ }^{3}$ Kırgızistan Türkiye Manas Üniversitesi, Ziraat Fakültesi, Bitki Koruma Bölümü, Bişkek, Kırgızistan
}

\section{To cite this article:}

Yıldırım, E., Karatoprak, K., Erper, i. \& Türkkan, M. (2020). Elmada mavi küfe neden olan Penicillium expansum'a karşı borik asitin antifungal etkisi. Harran Tarım ve Gıda Bilimleri Dergisi, 24(1): 64-72.

DOI: 10.29050/harranziraat.624445

Address for Correspondence: Elif YILDIRIM

e-mail:

elif.yildirim@omu.edu.tr

Received Date:

25.09.2019

Accepted Date:

24.02.2020

(C) Copyright 2018 by Harran University Faculty of Agriculture. Available on-line at www.dergipark.gov.tr/harranziraat

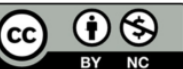

Öz

Bu çalışmada, borik asitin Penicillium expansum'a karşı etkinliği hem in vitro hem de in vivo koşullarda değerlendirilmiştir. In vitro' da, borik asitin \%0.125 konsantrasyonu $P$. expansum'un misel gelişmesini, spor çimlenmesini ve çim tüpü uzunluğunu sırasıyla $\% 68.88, \% 74.00$ ve $\% 85.50$ oranında azaltmış, halbuki daha yüksek konsantrasyonlar $(\% 0.25, \% 0.50, \% 1.00$ ve \%2.00)'ı ise tamamen engellemiştir. Ayrıca borik asitin yukarıda belirtilen ilk konsantrasyonu ve sonraki konsantrasyonlarının etkileri arasındaki fark istatistiksel olarak önemli bulunmuştur $(\mathrm{P}<0.05)$. Borik asitin $\mathrm{EC}_{50}$, minimum engelleyici konsantrasyon $(\mathrm{MIC})$ ve minimum fungisidal konsantrasyon (MFC) değerleri sırasıyla, 0.09, \%0.25 ve >\%2 olarak belirlenmiştir. In vivo denemelerde, borik asitin \%0.25 konsantrasyonu hariç, diğer tüm konsantrasyonlar $(\% 0.50$, \%1.00 ve \%2.00)'ı hem koruyucu hem de tedavi edici etki göstermişler ve bu konsantrasyonlar mavi küfün hastalık şiddetini patojen ile inokule edilmiş kontrole kıyasla önemli ölçüde azaltmıştır $(\mathrm{P}<0.05)$. Bununla birlikte, \%2.00 borik asitin hem koruyucu hem de tedavi edici uygulamalarda patojene karşı en etkili konsantrasyon olduğu ve hastalık şiddetini sırasıyla \%94.46 ve \%91.41 oranında azalttığı gösterilmiştir. Bu sonuçlar, borik asitin elmalarda $P$. expansum'un neden olduğu mavi küf hastalığının mücadelesi için sentetik fungisitlere bir alternatif olarak kullanılabileceğini göstermektedir.

Anahtar Kelimeler: Elma, Mavi küf, Borik asit, Fungus, Alternatif mücadele.

\section{ABSTRACT}

Efficacy of boric acid against Penicillium expansum was evaluated under both in vitro and in vivo conditions in this study. In in vitro, $0.125 \%$ concentration of boric acid reduced mycelial growth, spore germination and germ tube elongation of $P$. expansum by $68.88 \%, 74.00 \%$ and $85.50 \%$ respectively, whereas the higher concentrations $(0.25 \%, 0.50 \%, 1.00 \%$ and $2.00 \%)$ of boric acid completely inhibited those of $P$. expansum. Moreover, the difference among the effects of the above-mentioned first concentration and subsequent concentrations of boric acid was statistically significant $(\mathrm{P}<0.05)$. The $\mathrm{EC}_{50}$, minimum inhibitory concentration (MIC) and minimum fungicidal concentration (MFC) values of boric acid were defined as $0.09,0.25 \%$ and $>2 \%$, respectively. In in vivo experiments, except for $0.25 \%$ boric acid, all the other concentrations $(0.50 \%, 1.00 \%$ and $2.00 \%)$ exhibited both protective and curative activity against $P$. expansum, and they significantly reducing the disease severity of blue mold in comparison to pathogen-inoculated control $(P<0.05)$. However, $2.00 \%$ boric acid has been shown to be the most effective concentration against the pathogen in both protective and curative applications, and reduce the disease severity by $94.46 \%$ and $91.41 \%$, respectively. These results indicate that the boric acid can be used as an alternative to synthetic fungicides for the control of blue mold disease caused by $P$. expansum in apples.

Key Words: Apple, Blue mold, Boric acid, Fungus, Alternative control. 


\section{Giriş}

Elma (Malus domestica Borkh.) Türkiye'de gelir oranı yüksek olan meyve türlerinden biri olup, 2017 verilerine göre 175.357 ha alandan 3.032.164 ton üretim miktarı ile Çin ve Amerika'nın ardından 3. sırada gelmektedir (FAO, 2019). Ülkemizde ise Isparta ili 717.401 tonluk elma üretimi ile ilk sırada yer almakta, bunu sırasıyla 588.442 ton ile Karaman, 429.036 ton ile Niğde, 289.085 ton ile Denizli ve 265.068 ton ile Antalya illeri takip etmektedir (TUiK, 2019). Birçok tarımsal üründe hasat sonrası biyotik ve abiyotik faktörlerden dolayı ortaya çıkan bozulmalar ekonomik olarak önemli kayıplara neden olmakta ve bu bozulmalar en fazla fungal patojenler tarafından oluşturulmaktadır (Agrios, 2005). Özellikle bu patojenlerin neden olduğu hastalıklar, ürünlerin hasadı, paketlenmesi, pazara nakli ve depolanması aşamalarında ortaya çıkmaktadır. Elmalarda hasat sonrasında görülen önemli fungal patojenler Penicillium expansum, Botrytis cinerea, Alternaria spp., Monilinia fructicola, Glomerella cingulata, Mucor pyriformis, Rhizopus stolonifer ve Aspergillus spp. olup, bunlardan $P$. expansum ve $B$. cinerea önemli ürün kayıplarına neden olmaktadırlar (Snowdon, 1990).

Mavi Küf hastalığı etmeni $P$. expansum, meyve kabuğunda oluşan yaralardan meyve içine girebilen önemli bir yara patojenidir. Elmanın da dahil olduğu 21 farklı cinse ait bitkide hastalık oluşturarak, depolanmış ürünlerde \%50'ye varan ürün kayıplarına neden olabilmektedir (Mari ve ark., 2002). P. expansum elmalarda oluşturduğu doğrudan zararının yanı sıra, kanserojen patulin mikotoksinini de üretmektedir (Janisiewicz, 1998). Hasat sonrası taze meyvelerde meydana gelen kayıpları önlemek için, dünyada yumuşak çekirdekli meyvelerde farklı aktif madde içeren fungisit (thiabendazole, thiophanate-methyl, pyrimethanil, imazalil, iprodione, fenhexamide, boscalid, cyprodinil+fluodioxonil, boscalid+pyraclostrobin, carbendazim, thiabendazole+imazalil)'ler kullanılmaktadır (Zhang ve Timmer, 2007; Anonymous, 2019a). Fungisitlerin insan ve diğer canlılar üzerindeki olumsuz etkilerine karşı toplumsal farkındalığın artması, fungisitlere karşı tolerant/dayanıklı patojen ırklarının ortaya çıkması ve çevre kirliliği gibi nedenlerden ötürü hastalık etmenlerinin kontrolünde fungisitlere alternatif olabilecek mücadele yöntemlerinin araştırılmasını gerekli hale getirmektedir (Conway ve ark., 2005; Temur ve Tirkyaki, 2012). Dünyada hasat sonu hastalıkların mücadelesinde fungisitlere alternatif olarak; biyolojik mücadele ve modifiye atmosfer (Grant ve Patterson, 1991) uygulamaları, organik ve inorganik tuzlar (Palou ve ark., 2007) ve bazı bor tuz tuzlarının (Qin ve ark., 2010; Cao ve ark., 2012) kullanımı, ışınlama ve sıcaklık uygulamalarının tekli veya diğer yöntemler ile kombine edilerek kullanılması şeklinde çok sayıda çalışma yapılmıştır (Conway ve ark., 2004; Karabulut ve ark., 2005; Palou ve ark., 2007; Temur ve Tiryaki, 2012).

Bor ve türevleri dünyada farklı alanlarda uzun yıllardan beri kullanılmaktadır. Türkiye 3.3 milyar ton (dünya rezervinin $\% 73$ 'ü) bor $\left(\mathrm{B}_{2} \mathrm{O}_{3}\right)$ rezervi ile dünyada ilk sırada yer almaktadır (Anonymous, 2019b). Bazı bor bileşiklerinin hasat sonu depolanmış meyvelerde zarara neden olan bazı fungal patojenlere karşı etkinlikleri farklı çalışmalarda gösterilmiştir (Rolshausen ve Gubler, 2005; Xuan ve ark., 2005; Qin ve ark., 2007; Cao ve ark., 2012; Shi ve ark., 2012; Li ve ark., 2012). Örneğin, Lai ve ark. (2016) in vitro koşullarda borik asitin $P$. expansum'un misel gelişimini engelleyici etkisi olduğunu göstermiştir. Aynı fungusa karşı potasyum tetraboratın etkinliği üzerine yapılan bir çalışmada, tuzun \%0.1 konsantrasyonda fungus misel gelişimini \%10-15 oranında azalttığı rapor edilmiştir (Qin ve ark., 2007). Başka bir çalışmada, aynı tuzun \%0.25 konsantrasyonda $P$. expansum' un misel gelişimini tamamen engellediği tespit edilmiştir (Cao ve ark., 2012). Potasyum tetraboratın artan konsantrasyonlarının üzümde kurşuni küf hastalığına neden olan $B$. cinerea'nın misel gelişimini, spor çimlenmesini ve çim tüpü uzamasını engelleyici etkileri tespit edilmiştir (Qin ve ark., 2010). Shi ve ark. (2012) mango meyvelerinde antraknoz hastalığı etmeni 
Colletotrichum gloeosporioides'e karşı uygulanan potasyum tetraboratın 20mM (\%0.61) konsantrasyonda meyvelerde lezyon oluşumunu yaklaşık \%47 oranında azalttığını belirlemişlerdir.

$\mathrm{Bu}$ çalışmada, borik asitin farklı konsantrasyonlarının in vitro koşullarda $P$. expansum'un misel gelişimi, spor çimlenmesi ve çim tüp uzunluğuna karşı engelleyici etkileri tespit edilmiştir. Ayrıca, in vivo koşullarda borik asitin patojene karşı koruyucu ve tedavi edici etkileri elma meyveleri üzerinde belirlenmiştir.

\section{Materyal ve Yöntem}

\section{Fungal kültür}

Çalışmada kullanılan $P$. expansum izolatı hasat sonu soğuk hava depolarına alınan ve mavi küf hastalığı görünen elma meyvelerinden izole edilmiştir. Patates dekstroz agar (PDA; Oxoid Ltd, Basingstoke, UK) üzerinde geliştirilen fungusun tek spor izolasyonu yapılmış ve morfolojik özelliklerine göre $P$. expansum olarak teşhis edilmiştir (Frisvard ve Samson, 2004). İolat çalışmada kullanılmadan önce, fungal kültürden elde edilen spor süspansiyonu $\left(1 \times 10^{5}\right.$ konidi $\left.\mathrm{mL}^{-1}\right)$ ile sağlıklı elma meyveleri inokule edilerek izolatın virülensliği doğrulanmıştır. Bu izolat Ondokuz Mayıs Üniversitesi Ziraat Fakültesi Bitki Koruma Bölümü Mikoloji laboratuvarındaki fungal kültür koleksiyonunda $4^{\circ} \mathrm{C}^{\prime}$ de muhafaza edilmektedir.

\section{Borik asit}

Çalışmada kullanılan borik asit $\left(\mathrm{H}_{3} \mathrm{BO}_{3}\right)$ Eti Maden İşletmeleri Genel Müdürlüğü (Keçiören, ANKARA)'nden temin edilmiştir.

\section{Borik asitin misel gelişimi üzerine etkisinin} belirlenmesi

Borik asitin farklı konsantrasyonları (\%0.0625, $0.125,0.25,0.5,1.0$ ve $2.0, \mathrm{w} / \mathrm{v}$ ) otoklavda sterilize edilmiş ve yaklaşık $50^{\circ} \mathrm{C}^{\prime}$ ye soğutulmuş $100 \mathrm{~mL}$ 'lik erlenlerdeki PDA besi ortamına eklenmiş ve daha sonra manyetik karıştırıcı ile tuzun besi ortamına homojen olarak karışması sağlanmıştır. Tuzun farklı konsantrasyonlarını içeren PDA besi ortamı, $6 \mathrm{~cm}$ çapındaki steril
Petrilere 8-10 mL olacak şekilde dökülmüştür. PDA besi ortamında 7-10 gün geliştirilmiş $P$. expansum izolatına ait kültürlerden cork borer ile alınan $4 \mathrm{~mm}$ çaplı misel diskleri yukarıdaki konsantrasyonları içeren Petrilere aktarılmış ve inkübatör (Memmert ICP 110, Germany)'de $21 \pm 1^{\circ} C^{\prime}$ de inkübasyona bırakılmıştır. Aynı koşullarda sadece PDA besi ortamı içeren (tuz eklenmemiş) kontrol grubu Petrilerde inkübe edilen fungusun gelişimleri günlük olarak izlenmiştir. Petriyi kaplamaya yakın olduğunda, kontrol ve farklı tuz konsantrasyonlarını içeren Petrilerdeki fungusun gelişimleri dijital kumpas ile ölçülmüştür. Ölçümlerde her Petrideki fungusun en uzun ve en kısa radyal gelişimleri esas alınarak, misel gelişiminin engellenmesi MGE (\%) = [kpmg tpmg / kpmg (kontrol)] $\times 100$ formülü kullanılarak hesaplanmıştır. Formülde MGE (\%), misel gelişiminin yüzde olarak engellemesini; kpmg, kontrol Petrilerindeki misel gelişimini; tpmg, tuz eklenmiş Petrilerdeki misel gelişimini ifade etmektedir. Deneme her bir tuz konsantrasyonu için 5 tekerrürlü olarak yürütülmüştür (Türkkan ve Erper, 2015).

Borik asitin konidi çimlenmesi ve çim tüpü uzunluğu üzerine etkisinin belirlenmesi

Penicillium expansum izolatı PDA besi ortamında $21 \pm 1^{\circ} \mathrm{C}^{\prime}$ de $7-10$ gün geliştirilmiş ve gelişen fungal kültürün üzerine steril saf su eklenmiş ve steril bir spatül kullanılarak konidilerin suya geçmeleri sağlanmıştır. Elde edilen süspansiyondan misel kalıntılarını uzaklaştırmak için 4 kat steril tülbentten geçirilmiş ve \% 0.03 oranında Tween 20 damlatılmıştır. Süspansiyondaki konidi konsantrasyonu, Thoma lamı (hemocytometre) kullanılarak $1 \times 10^{5}$ konidi $\mathrm{mL}^{-1}$ ye ayarlanmıştır.

Borik asitin 5 farklı konsantrasyonu (\%0.0625, $0.125,0.25,0.5,1.0$ ve $2.0, \mathrm{w} / \mathrm{v}$ ) otoklav edilmiş ve yaklaşık $50^{\circ} \mathrm{C}^{\prime}$ ye soğutulmuş PDA besi ortamlarına eklenmiştir. Tuz manyetik karıştırıcı yardımı ile homojen bir şekilde karıştırılmış ve 6 $\mathrm{cm}$ çapındaki steril Petrilere $8-10 \mathrm{~mL}$ olacak şekilde dökülmüştür. Tuz eklenmiş ve eklenmemiş (kontrol) PDA besi ortamı içeren her Petriye, spor 
süspansiyonu $\left(1 \times 10^{5}\right.$ konidi $\left.\mathrm{mL}^{-1}\right)$ mikropipet kullanılarak $30 \mu \mathrm{L}$ yayılmıştır. Petriler $21 \pm 1^{\circ} \mathrm{C}^{\prime} \mathrm{de}$ 24 saat inkübasyona bırakılmış ve konidi çimlenme oranı (\%), her tuza ait farklı konsantrasyonlarda 400 konidi olmak üzere Olympus CX-31 model mikroskopta 100-400x büyütmede çimlenen ve çimlenmeyen konidiler sayılarak belirlenmiştir. Konidi büyüklüğü kadar çim tüpü oluşturmuş her bir konidi çimlenmiş olarak kabul edilmiştir (Mecteau ve ark., 2002).

Çalışmada çim tüpü uzunluklarının belirlenmesi amacıyla her konsantrasyon için aynı Petrilerdeki 100 konidinin çim tüpü uzunlukları oküler mikrometre kullanılarak ölçülmüştür. Çim tüp uzunluğunun engellenmesinde, ÇTUE (\%) = [(kpçtu - tpçtu) / kpçtu] x 100 formülüne göre hesaplanmıştır. Formülde ÇTUE (\%), Çim tüp uzunluğunun yüzde olarak engellenmesini; kpçtu, kontrol Petrilerindeki çim tüpü uzunluğunu; tpçtu, tuz eklenmiş Petrilerdeki çim tüpü uzunluğunu ifade etmektedir. Deneme her bir tuz konsantrasyonu için 5 tekerrürlü olarak yürütülmüştür.

\section{Borik asitin toksik etkilerinin belirlenmesi}

Penicillium expansum'un misel gelişmesini \%50 oranında azaltan konsantrasyon $\left(\mathrm{EC}_{50}=\right.$ etkili konsantrasyon) SPSS (Version 22, IBM Company, New York, USA)'in probit programı kullanılarak hesaplanmıştır. Misel gelişmesini tümüyle engelleyen en küçük konsantrasyon (MIC= minimum inhibitory concentration) paralel denemelerle belirlenmiştir (Türkkan ve ark., 2017).

Ayrıca tuzların fungisidal veya fungistatik etkileri Thompson (1989) ve Tripathi ve ark. (2004)'nın metodlarına göre belirlenmiştir. Buna göre borik asitin farklı konsantrasyonları uygulanmış Petrilerde gelişmeyen fungus diskleri buradan alınarak, taze PDA besi ortamı içeren Petrilere tekrar aşılanmış ve $21 \pm 1^{\circ} C^{\prime}$ de 9 gün inkübasyona bırakılmıştır. İnkübasyon sürecince fungusta geri dönüşümsüz olarak hiçbir gelişme gözlenmemişse, bu konsantrasyon fungusun misel gelişimine fungisidal etki yapan minimum fungisidal konsantrasyon $\quad$ (MFC $=$ minimum fungicidal concentration) olarak belirlenmiştir.
Borik asitin koruyucu ve tedavi edici etkilerinin belirlenmesi

Borik asitin in vivo koşullarda koruyucu ve tedavi edici uygulamalarında, in vitro'da etkili bulunan 4 farklı konsantrasyon (\%0.25, 0.5, 1.0 ve $2.0 \mathrm{w} / \mathrm{v}$ )'unun elma meyve (Granny Smith)'leri üzerinde $P$. expansum'a karşı etkinliğinin belirlenmesi amacıyla kullanılmıştır. Denemelerde kullanılan sağlıklı elma meyveleri musluk suyu altında yıkanıp, 1 gece kurumaya bırakılmıştır. Daha sonra bu meyveler yüzeysel dezenfeksiyon için \%1'lik NaOCl'de $3 \mathrm{dk}$ tutulmuş, 2 defa steril saf sudan geçirildikten sonra tekrar kurutularak yüzeysel dezenfeksiyon işlemi uygulanmış plastik viyollere yerleştirilmiştir. Steril kabin içinde bu elmaların ekvator bölgesine karşılıklı olacak şekilde, steril çelik bir tel ile $3 \mathrm{~mm}$ çapında 3-4 $\mathrm{mm}$ derinliğinde 2 adet yara açılmıştır.

Borik asitin koruyucu etkisinin belirlenmesi için, elma meyvelerinde yara açılma işleminin ardından meyveler steril kabin içinde 2 saat bekletilmiştir. Açılan yaralara önce steril su ile hazırlanan borik asitin farklı konsantrasyonlarından

alınan $25 \mu \mathrm{L}^{\prime}$ lik süspansiyon mikropipet yardımıyla açılan yaralara uygulanmıştır. Borik asit uygulaması yapılmıs bu yaralara, 2 saat sonra $\% 0.03$ 'lük Tween 20 içeren $1 \times 10^{5}$ konidi $\mathrm{mL}^{-1}$ süspansiyonundan $25 \mu \mathrm{L}^{\prime}$ lik miktar mikropipet yardımıyla uygulanmıştır. Borik asitin tedavi edici etkisinin belirlenmesinde ise, önce yukarıda belirtilen miktarda spor süspansiyonu meyve üzerinde açılan yaralara mikropipet yardımıyla aynı şekilde uygulanmış ve inkübasyona bırakılmıştır. Bu yaralara aynı tuz konsantrasyonları aynı miktarda 24 saat sonra eklenmiştir.

Her iki uygulamada da negatif kontrol amacıyla meyvede açılan yaralara aynı miktarda $\% 0.03$ 'lük Tween 20 içeren steril saf su, pozitif kontrol olarak ise patojenin spor süspansiyonu aynı miktarda $\left(1 \times 10^{5}\right.$ konidi $\left.\mathrm{mL}^{-1}\right)$ uygulanmış, plastik viyollere konulan elmalar inkübatörde $21^{\circ} \mathrm{C}$ 'de inkübasyona bırakılmış ve inokülasyondan 7 gün sonra enfekteli meyveler kontrol edilmiştir (Droby ve ark., 2003). Elmalar üzerindeki lezyon alanını belirlemek amacıyla 7 . 
günün sonunda lezyonlu alan üzerine konan asetat kağıdına fungal gelişmenin sınırları çizilmiştir. Asetat kağıtlarındaki çizimler üzerinde $5 \mathrm{~cm}$ 'lik bar olan beyaz A4 kağıtlarına aktarılmış ve Mustek 1200 UB Plus (Mustek Systems, Inc., Hsin Chu, Taiwan, PRC), masaüstü scanner ile taranarak 24-bit bmp dosyası olarak kaydedilmiştir. Digimizer programı (Version 4.0.0.0 for Windows 2005-2011 MedCalc Software bvba Broekstraat 52, 9030 Mariakerke, Belçika) kullanılarak lezyon alanları hesaplanmıştır (Türkkan ve Erper, 2015). Denemeler tesadüf parselleri deneme desenine göre 5 tekerrürlü olarak yürütülmüş, her bir elma meyvesi bir tekerrür olarak kabul edilmiştir (Nunes ve ark., 2001; Türkkan ve ark., 2017).

\section{istatistik analiz}

Çalışmada elde edilen veriler ayrı ayrı tek yönlü varyans analizine tabi tutulmuş ve ortalamalar arasındaki önemli farklılıklar XLSTAT (Version 2016.02.28451, Addinsoft Company) programı kullanılarak Fisher's LSD $(\mathrm{P}<0.05)$ testi ile belirlenmiştir.

\section{Bulgular ve Tartışma}

Borik asitin P. expansum'un misel gelişimi, konidi çimlenmesi ve çim tüpü uzunluğuna etkisi

Borik asitin artan konsantrasyonlarına paralel olarak $P$. expansum'un misel gelişimi üzerine engelleyici etkilerinde de artış gözlenmiştir. Borik asitin $\% 0.0625,0.125$ ve 0.25 konsantrasyonları fungusun misel gelişimini sırasıyla \%24.99, 68.88 ve 100 oranında engellemiştir. Tuzun daha yüksek konsantrasyonlarının misel gelişimi üzerine etkileri \%0.25 konsantrasyon ile benzerlik göstermiştir. Ayrıca, misel gelişimini tamamen engelleyen konsantrasyonlar istatistiksel olarak diğer konsantrasyonlardan önemli ölçüde farklı bulunmuştur $(\mathrm{P}<0.05)$ (Çizelge 1$)$.

Borik asitin $\% 0.25$ ve üzeri konsantrasyonlarda fungusun hem spor çimlenmesini hem de çim tüp uzunluğunu tamamen engellendiği belirlenmiştir (Çizelge 1). Tuzun \%0.0625 ve 0.125 konsantrasyonlarda spor çimlenmesini ve çim tüpü uzunluğunu tamamen engelleyemediği tespit edilmiştir. Dolayısıyla, hem spor çimlenmesinde hem de çim tüpü uzunluğunda tam engellemenin gerçekleştiği konsantrasyonlar (\%0.25-2.00)'dan bu iki konsantrasyon istatistiksel olarak önemli farklılık gösterdiği belirlenmiştir $(\mathrm{P}<0.05)$.

Önceki çalışmalardan elde bulgular ile mevcut çalışmanın uyum içerisinde olduğu görülmektedir (Qin ve ark., 2010; Thomidis ve Exadaktylou, 2010; Cao ve ark., 2012, Li ve ark., 2012, Shi ve ark., 2012). Çalışmamıza benzer olarak Lai ve ark. (2016)'nın yaptığı çalışmada in vitro koşullarda borik asitin $P$. expansum'un gelişmesinde engelleyici etkisi olduğunu tespit etmişlerdir.

Çizelge 1. Borik asitin artan konsantrasyonlarının Penicillium expansum'un misel gelişimi üzerine engelleyici etkisi (\%) Table 1. The inhibitory effect of increasing concentrations of boric acid on mycelial growth of Penicillium expansum (\%)

\begin{tabular}{|c|c|c|c|c|}
\hline \multirow[t]{2}{*}{$\begin{array}{l}\text { Tuz } \\
\text { Salt }\end{array}$} & \multirow[t]{2}{*}{$\begin{array}{l}\text { Konsantrasyon }(\%, w / v) \\
\text { Concentration }(\%, w / v)\end{array}$} & \multicolumn{3}{|c|}{$\begin{array}{l}\text { Engelleme (\%) } \\
\text { Inhibition (\%) }\end{array}$} \\
\hline & & $\begin{array}{c}\text { Misel gelişimi } \\
\text { Mycelial growth }\end{array}$ & $\begin{array}{l}\text { Spor çimlenme } \\
\text { Spore germination }\end{array}$ & $\begin{array}{l}\text { Çim tüp uzunluğu } \\
\text { Germ tube elongation }\end{array}$ \\
\hline Borik asit & 0.0625 & $24.99 \pm 2.46 c^{*}$ & $39.75 \pm 0.85 c$ & $50.75 \pm 1.55 \mathrm{c}$ \\
\hline \multirow[t]{5}{*}{ Boric acid } & 0.125 & $68.88 \pm 2.22 b$ & $74.00 \pm 0.85 b$ & $85.50 \pm 2.02 b$ \\
\hline & 0.25 & $100.00 \pm 0.00 \mathrm{a}$ & $100.00 \pm 0.00 \mathrm{a}$ & $100.00 \pm 0.00 \mathrm{a}$ \\
\hline & 0.50 & $100.00 \pm 0.00 \mathrm{a}$ & $100.00 \pm 0.00 \mathrm{a}$ & $100.00 \pm 0.00 \mathrm{a}$ \\
\hline & 1.00 & $100.00 \pm 0.00 \mathrm{a}$ & $100.00 \pm 0.00 \mathrm{a}$ & $100.00 \pm 0.00 \mathrm{a}$ \\
\hline & 2.00 & $100.00 \pm 0.00 \mathrm{a}$ & $100.00 \pm 0.00 \mathrm{a}$ & $100.00 \pm 0.00 \mathrm{a}$ \\
\hline $\begin{array}{l}\text { Kontrol } \\
\text { Control }\end{array}$ & 0.00 & $0.00 \pm 0.00 \mathrm{~d}$ & $0.00 \pm 0.00 \mathrm{~d}$ & $0.00 \pm 0.00 \mathrm{~d}$ \\
\hline
\end{tabular}

*Aynı sütünda yer alan ve aynı harfle gösterilen ortalamalar arasında Fisher's LSD $(P<0.05)$ testine göre fark yoktur. 
Cao ve ark., (2012), hünnap meyvesinde mavi küf hastalığına neden olan $P$. expansum'a karşı potasyum tetraboratın artan konsantrasyonuna paralel olarak misel gelişiminin engellenmesinin de arttığını rapor etmişlerdir. Aynı çalışmada tuzun $\% 0.01$ ve 0.05 konsantrasyonlarda fungus misel gelişimi engellenmezken, \%0.1'de \%10-15 oranında, $\% 0.25$ te ise tamamen engellendiği gözlenmiştir. Benzer olarak yapılan başka bir çalışmada ise \%1 konsantrasyonda potasyum tetraboratın $B$. cinerea (bağda kurşuni küf etmeni)'nın misel gelişimini tamamen engellediği ve $\% 0.1$ ve $\% 0.05$ konsantrasyonlarda spor çimlenmesini ve çim tüpü uzunluğunu önemli ölçüde azalttığı bildirilmiştir $(P<0.05)$ (Qin ve ark. 2010). Li ve ark., (2012), patateste kuru çürüklüğe neden olan Fusarium sulphureum'e karşı potasyum tetraborat $\left(\mathrm{K}_{2} \mathrm{~B}_{4} \mathrm{O}_{7}\right)$ ve boraks $\left(\mathrm{Na}_{2} \mathrm{~B}_{4} \mathrm{O}_{7}\right)^{\prime}$ ın etkinliğini belirlemek için yaptıkları çalışmada, artan tuz konsantrasyonları ile fungusun spor çimlenmesinin ve misel gelişiminin engellenmesi arasında pozitif bir ilişki olduğunu, özellikle çalışmada kullanılan en yüksek konsantrasyon $\left(20 \mathrm{~g} \quad \mathrm{~L}^{-1}=\% 2, \mathrm{w} / \mathrm{v}\right)^{\prime} \mathrm{da}$ engellemenin \%100 olduğunu tespit etmişlerdir. Potasyum tetraboratın $20 \mathrm{mM}$ (\%0.61) konsantrasyonunun $C$. gloeosporioides (mango meyvelerinde antraknoz hastalığı)'ın spor çimlenmesini ve çim tüp uzunluğunu sırasıyla yaklaşık \%72 ve \%94 oranında azalttığı (Shi ve ark., 2012), \%0.1'lik konsantrasyonda ise $P$. expansum'un spor çimlenmesini ve çim tüpü uzunluğunu yaklaşık $\% 12$ ve $\% 82$ oranında azalttığı bildirilmiştir (Qin ve ark., 2007).

\section{Borik asitin toksisitesi}

Çalışmada kullanılan borik asitin $P$. expansum'un misel gelişimi üzerine olan toksik etkisi değerlendirildiğinde $\mathrm{EC}_{50}$ değerinin \%0.09 olduğu görülmüştür. Tuzun fungistatik etkinliğinin (MIC değerinin) \%0.25'te gerçekleştiği ve fungisidal (fungitoksik) konsantrasyonun (MFC değerinin) ise $\% 2$ 'den büyük olduğu tespit edilmiştir.

Yapılan benzer çalışmalarda farklı bor ve diğer bazı organik ve inorganik tuzların bitki patojeni funguslara karşı toksik etkilerinin olduğu bildirilmiştir (Rolshausen ve Gubler, 2005; Thomidis ve Exadaktylou, 2010; Li ve ark., 2012; Türkkan ve ark., 2017). Thomidis ve Exadaktylou, (2010) Monilia laxa (şeftalilerde kahverengi çürüklük)'ya karşı uyguladıkları boraks ve Power $\mathrm{B}^{\prime}$ nin $\mathrm{EC}_{50}$ değerlerinin sırasıyla 107.9 ve $522.4 \mu \mathrm{g}$ $\mathrm{mL}^{-1}$ olarak tespit etmişlerdir. Başka bir çalışmada Eutypa lata'nın misel gelişiminin engellenmesinde

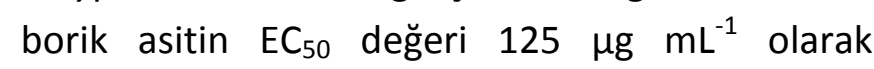
belirlenmiştir (Rolshausen ve Gubler, 2005). Li ve ark. (2012) potasyum tetraborat ve boraksın $F$. sulphureum'un misel gelişimi üzerine etkili konsantrasyon ( $E_{50}$ değerleri)'un sırasıyla 2.8 ve $3.2 \mathrm{~g} \mathrm{~L}^{-1}$ olarak tespit etmişlerdir. Türkkan ve ark. (2017)'nın B. cinerea'ya karşı test ettikleri 6 farklı tuz içinde amonyum karbonat, amonyum bikarbonat ve sodyum karbonat tuzlarının etkili konsantrasyon ( $\mathrm{EC}_{50}$ değeri) değerlerinin $<10 \mathrm{mM}$ olduğunu, sonuçta bu tuzların diğer 3 tuz (potasyum karbonat, potasyum bikarbonat ve sodyum bikarbonat)'a kıyasla daha toksik olduğu ve MIC değerlerinin sırasıyla 25,10 ve $25 \mathrm{mM}$ olduğunu bildirmişlerdir.

Elma meyveleri üzerinde borik asitin $P$. expansum'a karşı koruyucu ve tedavi edici etkileri

in vivo çalışmalarda, borik asitin farklı konsantrasyonlarının elma mavi küf hastalığına karşı koruyucu ve tedavi edici etkinlikleri değerlendirildiğinde, \%0.25'lik konsantrasyonun üzerindeki tüm konsantrasyonlarda meyve üzerindeki lezyon alanının patojen ile inokule edilmiş pozitif kontrole kıyasla önemli oranda azalttığı belirlenmiştir $(\mathrm{P}<0.05)$ (Çizelge 2; Şekil 1). Dahası borik asitin \%0.50, 1.0 ve $2.0^{\prime}$ lik konsantrasyonlarının koruyucu uygulamada hastalık şiddetini sırasıyla \%40.00 $\left(5.85 \mathrm{~cm}^{2}\right)$, $\% 74.87\left(2.45 \mathrm{~cm}^{2}\right)$ ve $\% 94.46\left(0.54 \mathrm{~cm}^{2}\right)$ oranında azaltırken, tedavi edici uygulamada \%33.07 (6.86 $\left.\mathrm{cm}^{2}\right), \% 77.27\left(2.33 \mathrm{~cm}^{2}\right)$ ve \%91.41 $\left(0.88 \mathrm{~cm}^{2}\right)$ oranında azalttığı tespit edilmiştir.

Her iki uygulamada da hastalık gelişimi üzerine en etkili konsantrasyonun \%2 olduğu ve diğer konsantrasyonlardan istatistiksel olarak önemli bir farklılık gösterdiği belirlenmiştir $(P<0.05)$. 
Çizelge 2. Elmada mavi küf etmeni Penicillium expansum'a karşı borik asitin farklı konsantrasyonlarının koruyucu ve tedavi edici etkileri (in vivo)

Table 2. Protective and curative effects of different concentrations of boric acid against blue mold agent Penicillium expansum on apple (in vivo)

\begin{tabular}{cccc}
\hline & $\begin{array}{c}\text { Konsantrasyon } \\
(\%, w / v) \\
\text { Concentration } \\
(\%, w / v)\end{array}$ & \multicolumn{2}{c}{$\begin{array}{c}\text { Lezyon alanı }\left(\mathrm{cm}^{2}\right) \\
\text { Lesion area }\left(\mathrm{cm}^{2}\right)\end{array}$} \\
\cline { 3 - 4 } & 0.25 & $\begin{array}{c}\text { Koruyucu } \\
\text { Protective }\end{array}$ & $\begin{array}{c}\text { Tedavi Edici } \\
\text { Curative }\end{array}$ \\
\hline \multirow{3}{*}{ Borik Asit } & 0.50 & $5.85 \pm 0.38 \mathrm{a}$ & $9.50 \pm 0.23 \mathrm{a}$ \\
Boric Acid & 1.00 & $2.45 \pm 0.29 \mathrm{c}$ & $6.86 \pm 0.38 \mathrm{~b}$ \\
& 2.00 & $0.54 \pm 0.07 \mathrm{~d}$ & $0.88 \pm 0.27 \mathrm{c}$ \\
& Pozitif Kontrol & $9.75 \pm 0.32 \mathrm{a}$ & $10.25 \pm 0.43 \mathrm{a}$ \\
\hline
\end{tabular}

Aynı sütunda yer alan ve aynı harfle başlayan ortalamalar arasındaki farklılık Fisher's LSD testine göre istatistiksel olarak önemsizdir $(\mathrm{P}<0.05)$.

Elde ettiğimiz bulgular daha önce hasat sonu hastalıklarının mücadelesinde kullanılan bor ve diğer tuz bileşiklerinin uygulamaları ile benzerlik göstermektedir. Domateslerde meyve çürüklüğüne neden olan çeşitli fungus (Alternaria alternata, Fusarium oxysporum, Geotrichum candidum, $R$. stolonifer, Aspergillus flavus ve $A$. niger)'lara karşı farklı tuz ve fungisitlerin kullanıldığı bir çalışmada, \%0.4, \%0.5 ve \%0.6'lık konsantrasyonlarda kullanılan borik asit ve boraks uygulamalarının patojen ile inokuleli kontrole kıyasla domateslerde hastalık şiddetini önemli oranda azalttığı bildirilmiştir (Akhtar ve ark., 1994). Shi ve ark., (2012) yaptıkları çalışmada mango meyvelerinde $C$. gloeosporioides'in neden olduğu antraknoz hastalığına karşı potasyum tetraboratın \%0.2 konsantrasyonda, uygulama yapılmış kontrol meyvelerine göre lezyon oluşumunu yaklaşık \%47 oranında azalttığını tespit etmişlerdir.

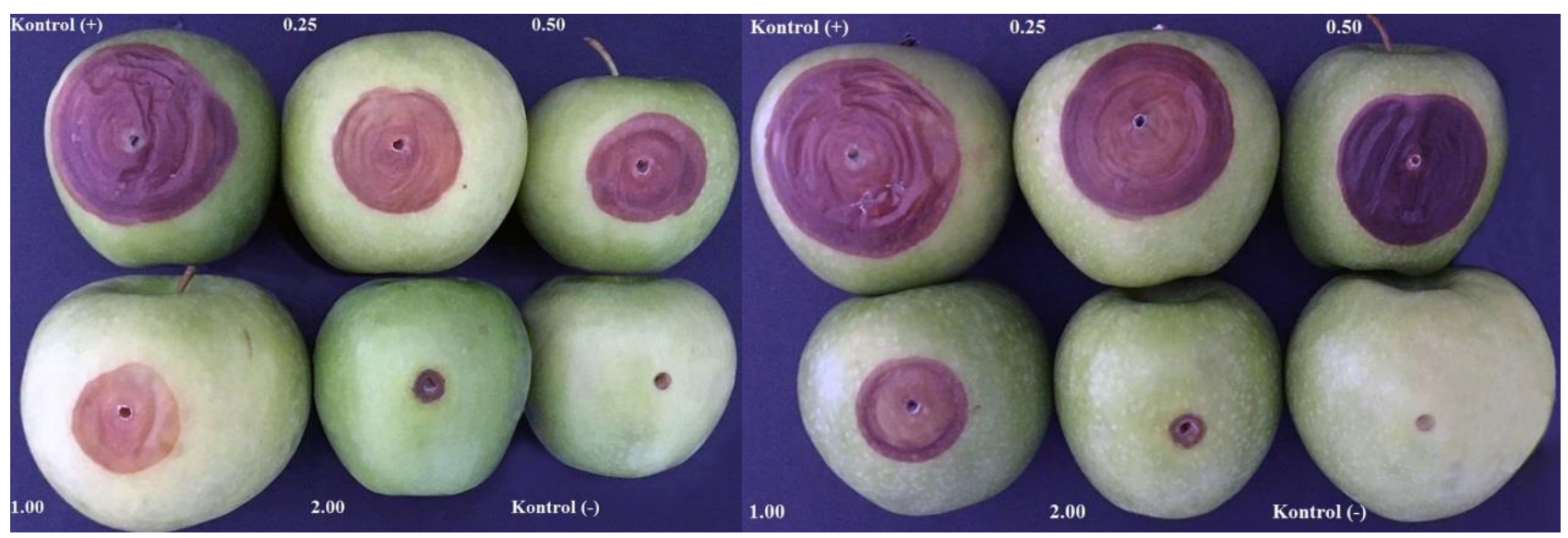

Şekil 1. Elmada mavi küf etmeni Penicillium expansum'a karşı borik asitin farklı konsantrasyonlarının koruyucu ve tedavi edici etkileri

Figure 1. Protective and curative effects of different concentrations of boric acid against blue mold agent Penicillium expansum on apple

Çalışmamızda kullanılan $P$. expansum izolatına karşı in vitro koşullarda etkili bulunan tuz konsantrasyonlarının in vivo koşullarda da etkili olduğu gözlenmiştir. Ancak Wisniewski ve ark., (1998) P. digitatum ve B. cinerea'ya karşı kullanılan farklı bileşiklerin in vitro ve in vivo engelleyici etkileri arasında bir ilişki olmadığını rapor etmişlerdir. Tuzların koruyucu ve tedavi edici etkiler tuz, konukçu bitki dokusu ve patojen arasındaki etkileşime bağlı olabilir. Ayrıca bu belirli tuzlara özgü konukçu savunma mekanizmaları gibi kimyasal, fizyokimyasal veya biyokimyasal reaksiyonları içerebilir.

\section{Sonuçlar}

Sonuç olarak, borik asitin bazı konsantrasyonlarının hem in vitro hem de in vivo koşullarda, $P$. expansum'un neden olduğu elmada mavi küf hastalığının mücadelesinde etkili olduğu tespit edilmiştir. Bor bileşiklerinin antifungal etkisi, patojenin hücre zarını bozarak, sitoplazmik materyallerin dışarı çıkması ve sonuçta patojenin ölümüne yol açması şeklinde olabilmektedir (Qin ve ark., 2010). Elma meyveleri üzerine uygulanan borik asitin en yüksek konsantrasyonu (\%2.0)'nda bile meyveler üzerinde hiçbir şekilde fitotoksisite görülmemiş olması, bu bileşiklerin farklı 
patojenlerin mücadelesinde de potansiyel olarak kullanılabileceğini göstermektedir. Bor, bitkiler için gerekli bir mikroelement olup, fungus, bakteri ve birçok böceğin mücadelesi için tarımda yaygın olarak kullanılmaktadır (Qin ve ark. 2010). Ayrıca hasat sonu fungal hastalıkların entegre mücadelesi için borun diğer geniş spektrumlu antimikrobiyal özelliğe sahip ve genellikle güvenli kabul edilen (GRAS) organik ve inorganik tuzlarla kombinasyon halinde etkinliklerinin belirlenmesine yönelik yapılacak çalışmalara intiyaç vardır.

\section{Kaynaklar}

Agrios, G. N. (2005). Plant pathology. Academic press.

Akhtar, K. P., Matin, M., Mirza, J. H., Shakir, A. S. ve Rafique, M. (1994). Some studies on the post harvest diseases of tomato fruits and their chemical control. Pakistan Journal of Phytopathology, 6, 125-129.

Anonymous (2019a). Bitki koruma ürünleri veri tabanı (BKU). https://bku.tarim.gov.tr.

Anonymous (2019b). https://www.enerji.gov.tr/trTR/Sayfalar/Bor.

Cao, B., Li, H., Tian, S. ve Qin, G. (2012). Boron improves the biocontrol activity of Cryptococcus laurentii against Penicillium expansum in jujube fruit. Postharvest Biology and Technology, 68, 16-21.

Conway, W. S., Leverentz, B., Janisiewicz, W. J., Blodgett, A. B., Saftner, R. A. ve Camp, M. J. (2004). Integrating heat treatment, biocontrol and sodium bicarbonate to reduce postharvest decay of apple caused by Colletotrichum acutatum and Penicillium expansum. Postharvest Biology and Technology, 34(1), 11-20.

Conway, W. S., Leverentz, B., Janisiewicz, W. J., Saftner, R. A. ve Camp, M. J. (2005). Improving biocontrol using antagonist mixtures with heat and/or sodium bicarbonate to control postharvest decay of apple fruit. Postharvest Biology and Technology, 36(3), 235-244.

Droby, S., Wisniewski, M., El Ghaouth, A. ve Wilson, C. (2003). Influence of food additives on the control of postharvest rots of apple and peach and efficacy of the yeast-based biocontrol product Aspire. Postharvest Biology and Technology, 27(2), 127-135.

FAO, (2019). http://www.fao.org/faostat/en/\#data/QC.

Frisvad, J. C. ve Samson, R. A. (2004). Polyphasic taxonomy of Penicillium subgenus Penicillium. A guide to identification of food and air-borne terverticillate Penicillia and their mycotoxins. Studies in mycology, 49(1), 1-174.

Grant, I. R. ve Patterson, M. F. (1991). Effect of irradiation and modified atmosphere packaging on the microbiological safety of minced pork stored under temperature abuse conditions. International journal of food science \& technology, 26(5), 521-533.

Janisiewicz, W. J. (1998). Biocontrol of postharvest diseases of temperate fruits. Plant-microbe interactions and biological control, 171-198.

Karabulut, O. A., Arslan, U., Illhan, K. ve Kuruoğlu, G. (2005). Integrated control of postharvest diseases of sweet cherry with yeast antagonists and sodium bicarbonate applications within a hydrocooler. Postharvest biology and technology, 37(2), 135-141.

Lai, T., Wang, Y., Bai, X., Qi, Q., Xu, M. ve Zhou, T. (2016). Dissecting inhibitory effect of boric acid on virulence and patulin production of Penicillium expansum. Postharvest Biology and Technology, 117, 187-196.

Li, Y., Yang, Z., Bi, Y., Zhang, J. ve Wang, D. (2012). Antifungal effect of borates against Fusarium sulphureum on potato tubers and its possible mechanisms of action. Postharvest biology and technology, 74, 55-61.

Mari, M., Leoni, O., Iori, R. ve Cembali, T. (2002). Antifungal vapour-phase activity of allyl-isothiocyanate against Penicillium expansum on pears. Plant pathology, 51(2), 231-236.

Mecteau, M. R., Joseph, A. R. U. L. ve Tweddell, R. J. (2002). Effect of organic and inorganic salts on the growth and development of Fusarium sambucinum, a causal agent of potato dry rot. Mycological Research, 106(6), 688-696.

Nunes, C., Usall, J., Teixidó, N., Eribe, X. O. D. ve Viñas, I. (2001). Control of post-harvest decay of apples by pre-harvest and post-harvest application of ammonium molybdate. Pest Management Science: formerly Pesticide Science, 57(12), 1093-1099.

Palou, L., Marcilla, A., Rojas-Argudo, C., Alonso, M., Jacas, J. A. ve del Río, M. Á. (2007). Effects of X-ray irradiation and sodium carbonate treatments on postharvest Penicillium decay and quality attributes of clementine mandarins. Postharvest biology and technology, 46(3), 252-261.

Qin, G., Tian, S., Chan, Z. ve Li, B. (2007). Crucial role of antioxidant proteins and hydrolytic enzymes in pathogenicity of Penicillium expansum: analysis based on proteomics approach. Molecular \& Cellular Proteomics, 6(3), 425-438.

Qin, G., Zong, Y., Chen, Q., Hua, D. ve Tian, S. (2010). Inhibitory effect of boron against Botrytis cinerea on table grapes and its possible mechanisms of action. International Journal of Food Microbiology, 138(1-2), 145-150.

Rolshausen, P. E. ve Gubler, W. D. (2005). Use of boron for the control of Eutypa dieback of grapevines. Plant Disease, 89(7), 734-738.

Shi, X., Li, B., Qin, G. ve Tian, S. (2012). Mechanism of antifungal action of borate against Colletotrichum gloeosporioides related to mitochondrial degradation in spores. Postharvest Biology and Technology, 67, 138-143.

Snowdon, A. L. (1990). A colour atlas of post-harvest diseases and disorders of fruits and vegetables. Volume 1: General introduction and fruits. Wolfe Scientific Ltd.

Temur, C. ve Tiryaki, O. (2012). Combination of Irradiation 
and Sodium Carbonate to Control Postharvest Penicillium Decay of Apples. The Journal of Turkish Phytopathology, 42(1-2-3), 47-56.

Thomidis, T. ve Exadaktylou, E. (2010). Effect of boron on the development of brown rot (Monilinia laxa) on peaches. Crop protection, 29(6), 572-576.

Thompson, D. P. (1989). Fungitoxic activity of essential oil components on food storage fungi. Mycologia, 81(1), 151-153.

Tripathi, P., Dubey, N. K., Banerji, R. ve Chansouria, J. P. N. (2004). Evaluation of some essential oils as botanical fungitoxicants in management of post-harvest rotting of citrus fruits. World Journal of Microbiology and Biotechnology, 20(3), 317-321.

TUiK, (2019). Türkiye İstatistik Kurumu (TÜiK). https://tuik.gov.tr.

Türkkan, M. ve Erper, i. (2015). Inhibitory influence of organic and inorganic sodium salts and synthetic fungicides against bean root rot pathogens. Gesunde Pflanzen, 67(2), 83-94.
Türkkan, M., Özcan, M. ve Erper, İ. (2017). Antifungal effect of carbonate and bicarbonate salts against Botrytis cinerea, the casual agent of grey mould of kiwifruit. Akademik Ziraat Dergisi, 6(2), 107-114.

Wisniewski, M. E., Droby, S., El-Ghaouth, A. ve Wilson, C. L. (1998). The use of food additives to control postharvest decay and enhance biocontrol activity of yeast antagonists. In Proc Internat Congress Plant Pathol, August (pp. 9-16).

Xuan, H., Streif, A., Römheld, V. ve Bangerth, F. (2005). Application of boron with calcium affects respiration and ATP/ADP ratio in 'Conference'pears during controlled atmosphere storage. The Journal of Horticultural Science and Biotechnology, 80(5), 633637.

Zhang, J. ve Timmer, L. W. (2007). Preharvest application of fungicides for postharvest disease control on early season tangerine hybrids in Florida. Crop Protection, 26(7), 886-893. 